\title{
Verandering en vernuwing in die pastoraat met vroue
}

Y Dreyer

(Universiteit van Pretoria)

\section{ABSTRACT}

\section{Change and renewal in pastoral counseling with women}

The aim of the article is to describe and explain the paradigm shift from a modern to a postmodern mindset regarding pastoral counseling with women. Modernistic thinking contributed to the non-identity of women, though more rights were gradually granted to women. The perspective from which theology approached women was still embedded is a premodern biblical mindset. This article elaborates on the hermeneutic of suspicion with the aim to enhancing a more symmetrical pastoral interaction. This symmetry is conducive to authentic communication, genuine respect for women as persons and for their stories. This provides an optimum environment for healing.

\section{INLEIDING - 'N PARADIGMASKUIF}

Die kerk as ' $n$ sosiale instelling wat binne die breër samelewing bestaan, het saam met die samelewing deel aan veranderings wat in die wêreld plaasvind, sowel wat geskiedkundige gebeurtenisse betref as wetenskaplike ontwikkelings. Hierdie gebeurtenisse, ontwikkelings en ander kragte, soos byvoorbeeld mobiliteit en die beskikbaarheid van inligting, beïnvloed die wyse waarop mense dink. Net soos die samelewing, is die kerk ook uitgelewer aan paradigmaveranderings (kyk Kuhn 1970:182; vgl Van Huyssteen 1986:63-87) en word beïnvloed en gevorm deur samelewingstendense. Die breë dinkraamwerke wat individuele denke vorm, bly nie staties nie. Daar vind van tyd tot tyd in die geskiedenis paradigmaskuiwe plaas (kyk Kuhn 1977:293-319; vgl Mouton 1987:57-79).

Hedendaagse geloofsgemeenskappe het met drie paradigmas te doen (Küng 1988:2; 1991:3-4). Die paradigma van die Bybelse tyd is pre-modern (kyk Du Toit 2000:13-61). Westerlinge het dikwels geen kennis van of kontak met die pre-moderne era nie. Dit is te ver verwyderd van hulle werklikheid. Aangesien die geloofsgemeenskap egter die stem van God spesifiek in die Bybel, ' $n$ produk van die pre-moderne era, probeer hoor, moet erns gemaak word met hierdie vreemde en onbekende era. Die onbekendheid van die dinkraamwerk in die leefwêreld van die Bybel maan die Bybelleser tot versigtigheid. In die eerste plek be- 
hoort die wêreldbeeld, sienings en gebruike van die Mediterreense tyd gerespekteer te word vir wat dit is.

Minder openlik en duidelik is die probleme wat die hedendaagse paradigmas kan veroorsaak. Dit is altyd moeilik, indien nie onmoontlik nie, om iets raak te sien as ' $n$ mens daar binne-in verkeer. Die kerk en die meeste mense in die samelewing staan op ' $n$ manier met een voet in die moderne en een voet in die postmoderne era. Die grootste trekkrag vir die mense in die teenswoordige kerk is waarskynlik steeds die dinkraamwerk van die moderniteit. Dit geld vir hulle alledaagse lewe, hoewel hulle teologie dikwels die pre-moderne mitologiese taal reflekteer. Die postmoderne, inligtingstegnologiese era is egter besig om toenemend voelbaar, hoorbaar en sigbaar te word, ook in die lewens van kerkmense.

In die pre-moderne era was die samelewing patriargaal en hiërargies georden (kyk Matthews \& Benjamin 1993:7-24). In hierdie orde was daar nie ' $n$ skeiding tussen die wêreld van God en die wêreld van mense nie (Pilch 1996:133-138). Mans was in ' $n$ sekere sin God se verteenwoordigers (kyk Hammerton-Kelly 1979:27). Die hiërargie het daaruit bestaan dat sommige mans met meer mag en status hoër geag is as ander mans met minder mag en status. Vroue, kinders en slawe was nie as eie entiteite deel van die hiërargiese ordening nie. Hulle is gesien as ingebed in die mans, behorende tot die mans (kyk Stegemann \& Stegemann 1995:309). Die mans was dus die enigste mense in die samelewing met die status van "persone" en "burgers". Die manspersone het beskik oor besittings: vroue, kinders, slawe, grond en goedere.

In die moderne era bestaan die hiërargie nie net uit mans en hulle besittings nie. Ander mense het nou ook ' $n$ plek in die hiërargiese ordening. In die hiërargie is God bo, mans tweede en daarna kom die minderes: vroue, kinders, ander rasse ensomeer. Hoewel hulle nou as eie entiteite funksioneer, bly hulle steeds laer in die hiërargie. Die mensheid word verdeel in "n hiërargie van instrumentele waarde/ bruikbaarheid. Aan sommige mense word daar meer waarde toegeken as aan ander. Dié met meer waarde regeer en heers oor dié met minder waarde.

Waar mense as "instrumente" beskou is, is vroue in die moderne era geag as bruikbaar vir sekere soorte arbeid, soos agter die spinwiel in fabrieke en in die myne. By die huis was vroue funksioneel vir die verskaffing van voedsel en 'n skoon woonruimte, en vir die voortbring van ' $n$ nageslag (kyk Sölle 1996:154). Beheer en kontrole word implisiet oor vroue uitgeoefen deur ekonomiese en seksuele mag (Mollenkott 1992:88-89; Schüssler Fiorenza 1996a:9). Wesenlik word vroue psigies beheer deurdat hulle as minderwaardig gedefinieer word: fisies ontoereikend, psigies en moreel swak of onderontwikkeld. Dit is waarom die Aristoteliese orde (Aristoteles, De Generatio Animalium II, 3:737a; kyk Wilshire 1992:93) in hierdie era weer van waarde geag word. Vroue word getipeer as passiewe, afhanklike en emosionele wesens. Dit is eienskappe wat nie deur die samelewing met respek bejeën word nie. Hoewel vroue in die moderne paradigma oënskynlik ' $n$ groter selfstandigheid bereik het, word hierdie era steeds gekenmerk deur ' $n$ man-georiënteerde, dominerende ordening van die samelewing.

In die opkomende postmoderne paradigma word hiërargie, dominansie en waarde-oordele oor mense bevraagteken. Die dinkraamwerk in hierdie era is daarom meer ideologie-krities as in enige voorafgaande tydperk (kyk Schüssler Fiorenza 1999:51). Die skade wat die sosiale ordening aan die waarde en waardigheid van mense berokken, word ontmasker. Stemme, ervarings en perspektiewe wat deur dominansie genegeer, stilgemaak en doodgemaak is, word gehoor. Verskeidenheid en pluraliteit word erken as die werklikheid van die menslike bestaan. Waar die moderne era eksklusief te werk gegaan het, is die postmoderne tendens inklusief. Waar die moderne era gefokus het op heerskappy oor ander, fokus die postmoderne op die waardevolle bydrae wat ander (kyk Beukes 1996:233-251) in simmetriese interaksie (vgl Vos \& Pieterse 1997:23) kan lewer. Die postmoderne tendens is om elke mens as ' $n$ volwaardige persoon en mede-subjek in menslike interaksie te reken (kyk Romm 1987:195; Snyman 1987:173).

In hierdie oorgangstyd tussen modern en postmodern is dit ' $\mathrm{n}$ vraag wáár op die kontinuum die kerk aangetref sal word. Die praktyk van die kerk (ook in die Reformatoriese tradisie) toon duidelik dat dit steeds ' $n$ man-georiënteerde, dominerende hiërargie verteenwoordig wat tegniese handeling van meer waarde ag as die estetiese houding (Snyman 1995:63-73). Die Reformatoriese ampsbeskouing is veronderstel om niehiërargies te wees. As gevolg van institusionalisering tydens die moderne era (kyk Weber [1947]1968:246-254, 1121-1148; vgl Lemmen 1990:137-145), is die praktyk van "magsuitoefening" in Reformatoriese kerke egter in baie opsigte steeds hiërargies. Waar beleid gemaak, besluite geneem, oordele oor mense se lewens gefel word, is dit hoofsaaklik deur mans gedoen. Taalgebruik in die kerk is meesal manlik (vgl Von Wartenberg-Potter 1987:43). Die manlike word onkrities aanvaar as die norm vir menswees en vanuit daardie normatiewe manlike perspektief word alles in die kerke bedryf: die liturgie, prediking, kerkregering, opsig en pastorale interaksie. Die leefwêreld in die kerk adem grootliks steeds die gees van moderniteit. En soos in alle samelewingstrukture waar "norme" gebruik word om gewoontes te legitimeer, vind dieselfde in die kerk plaas. Hier funksioneer die Skrif, die teologie en dikwels die dogmengeskiedenis as legitimasie.

Soos die kerk, bevind die pastor hom- of haarself êrens op die kontinuum tussen moderne en postmoderne denke. Die pastor kan aanhou om onkrities te bly funksioneer binne die moderne paradigma as die 
enigste en vanselfsprekende werklikheid. Verandering is nooit aangenaam of gemaklik nie. "Behoudend" of "konserwatief" as tipering vir persone of ' $n$ kerk, dui aan dat verandering nie maklik aanvaar word nie. Wat "behou" en "gekonserveer" wil word, is "hoe dinge altyd was". Dikwels word hierdie invalshoek in die kerk baie positief bejeën. Daar word nie altyd krities ingegaan op die vraag of wat behou en gekonserveer word, nie maar net die skeefgetrekte produkte van mense is nie. Pastors wat onkrities binne die moderne denkraamwerk bly funksioneer, sal geen probleem hê wanneer die mense met wie hulle in pastorale interaksie tree op dieselfde plek as hulleself staan nie. Die vraag is egter wat sal gebeur wanneer so " $n$ pastor te doen kry met mense wat hulleself op ' $n$ ander staanplek bevind, soos wat vandag meer en meer te wagte kan wees.

\section{SUBJEK-SUBJEK INTERAKSIE}

Die kommunikatiewe teoriee in die postmoderne filosofie wys daarop dat outentieke kommunikasie nie moontlik is in 'n subjek-objek relasie nie (kyk Dreyer 1998:623-651). Outentieke kommunikasie is alleen moontlik wanneer albei partye as volwaardige persone in eie reg en as mede-subjekte kan deelneem aan die gesprek. In dié kommunikasieteorieë is uitgewys dat daar in werklikheid nie so-iets soos ' $n$ ek-ditverhouding bestaan nie. Die oomblik wanneer ' $n$ mens ' $n$ ander persoon tot objek reduseer, kom die eie subjek-kwaliteit in die gedrang. Wat " $n$ ek-jy verhouding moes gewees het, word met objektivering van die ander ' $n$ ek-dit interaksie wat onvermydelik omslaan tot ' $n$ dit-dit relasie (kyk Cronjé \& Van Wyk 1982:151). In die proses van die objektivering van ' $n$ ander, ontmenslik ' $n$ mens jouself.

In die pastor se benadering is respek net so 'n belangrike komponent as empatie. Hierdie sentrale saak in die pastoraat kan soos volg beskryf word: "Empathy represents the attitude of openness toward others and the ability to understand them and to feel compassion. Empathy is a complex phenomenon: cognitive and emotional aspects are involved, and defensive and projective orientations are incorporated" (Nauta 1996:53). Empatie is dus duidelik nie net ' $n$ maklike, ongekompliseerde saak nie. Gekombineer met respek, bring empatie 'n mens uit by die Bybelse idee van naasteliefde. In hedendaagse taal omgesit, sou respek waarskynlik as ' $\mathrm{n}$ goeie ekwivalent vir naasteliefde kon dien. Sonder respek vir die menswaardigheid van die Ander kan die pastor geen goeie resultate van die pastorale interaksie verwag nie. Sonder respek is geen outentieke simmetriese kommunikasie moontlik nie. Respek is verder ook voorwaarde vir ' $n$ egte poging om die leefwêreld van die pastorant te betree deur middel van invoeling of empatie. Om ' $n$ mens te objektiveer, is om die mens se persoonskap an te tas en van die persoon 'n ding, 'n "dit" en 'n gebruiksartikel te maak. In 'n pastoraatteorie is so-iets uiteraard nie wenslik nie.

Pastors meen waarskynlik nie dat hulle die pastorant objektiveer en met disrespek benader nie. Die gebeur egter dikwels onbewustelik wel in pastorale interaksie met vroue. Institusionalisering bring mee dat die leefwêreld van pastors gedetermineer word deur die teologiese tradisie, pastoraat- en psigologiese teorieë wat spruit uit die modernistiese paradigma. In hierdie paradigma word vroue dikwels gereduseer tot nie-identiteit, identiteit alleen deur ander, tot minderwaardige rolle en ondergeskikte persone (kyk Dreyer 1999a:51-65). Sonder volwaardige persoonskap en identiteit, sonder volwaardige subjek-status word outentieke kommunikasie belemmer. Nie-identiteit het die gevolg van onvolwassenheid, gebrek aan volwaardige geestesgesondheid en waaragtige lewe voor God (kyk Conn 1986:9-30). Outentieke lewe veronderstel ' $n$ integrasie van alle aspekte van menswees.

Die doel van pastoraat is die heil, heling, welsyn en outentieke lewe voor God (kyk Heitink 1990:56-69). Die medium waardeur hierdie doel bereik word, is simmetriese kommunikasie. Dit manifesteer in die betoning van respek. Respek en empatie word beleef waar daar ' $n$ subjeksubjek interaksie tussen pastor en pastorant is. Albei partye, die pastor en die vrou, kan egter verhinder dat hierdie ideaal verwesenlik word. Wat die pastor betref, kan hy of sy (vanuit ' $n$ modernistiese beskouing) vroue soos objekte of kinders behandel en hulle terugdruk in voorgeskrewe rolle. Om voor te skryf veronderstel norme. Hierdie norme steun dikwels op ' $\mathrm{n}$ ongenuanseerde Bybelgebruik (vgl Schüssler Fiorenza 1983:30). Die ironie is egter dat vroue se God-gegewe gawes en talente dikwels in die proses genegeer word. Die pastor se ambivalente gevoelens kan ook 'n struikelblok wees:

"Because of its contextual nature, pastoral identity is always a compromise between personal preferences and situational requirements. The resulting ambiguity will be felt more deeply the more consciously other alternatives are foregone or the less acceptable the chosen solution is in the light of valued ideals" (Nauta 1996:54).

Reinard Nauta se empiriese studie oor pastors se identiteit het ook uitgewys dat, in vergelyking met die Rooms-Katolieke pastors wat ' $\mathrm{n}$ groter onbetrokkenheid en afstand van die pastorant handhaaf, "(p)rotestant ministers are overwhelmed by scare, helplessness, loss of control, general unease when challenged to identify with others who suffer and have lost faith" (Nauta 1996:66-67).

Waar die eerste probleem rondom die rol van pastors sentreer, kan die tweede probleem by vroue as pastorant lê. In die modernistiese para-

ISSN 1609-9982 = VERBUM ET ECCLESIA Jrg 22 (1) 2001 
digma is vroue gekondisioneer en gesosialiseer om te aanvaar dat hulle minderwaardige persone en nie-identiteite is en behoort te wees binne die sogenaamde God-gegewe orde. Hierdie paradigma funksioneer implisiet vanuit die gemelde Aristoteliese beskouing dat vroue "gebreklike mans" is. Vanuit so "n gebrekkige persoonskap is vroue nie in staat om as volwaardige subjekte binne ' $n$ relasie tot persone bokant hulle in die hiërargie te funksioneer nie. Pastors, mans of vroue, word volgens die dominante narratief (kommunikasie op 'n subjek-objek vlak - kyk Dreyer 1999a:51-65) bokant vroue as pastorante in die hiërargiese orde geplaas.

Pastors benader pastorante met die Bybel in die hand. Met ' $n$ hermeneutiese benadering sonder 'n hermeneutiek van suspisie (kyk Schüssler Fiorenza 1999:51) kan pastorante geobjektiveer en met behulp van die Bybel stilgemaak word. 'n Bewuswordings- en bewusmakingsproses sal daarom na albei kante toe moet werk sodat ' $n$ kritiese houding teenoor sowel die Bybel as die Bybelgebruiker gekweek word. Die bewusmakingsproses by pastors behoort gerig te wees op die ideaal om die vroue steeds meer as volledig persoon in eie reg te sien in plaas van as minderwaardige wese wat haar plek in die hiërargie inneem as ' $n$ aanhangsel, ondersteuner of gebruiksartikel van ' $n$ man. Dit sluit in om na vroue te luister met die doel om hulle werklik te hoor en binne hulle eie konteks te verstaan, om hulle te glo, om hulle ervaring as outentiek te erken, ook wanneer hulle self vanweë kondisionering met al hierdie dinge sukkel (vgl Laird 1989:437). Dit beteken dat pastors 'n eerlike poging sal aanwend om vroue se leefwêreld te betree deur middel van invoeling, hoe vreemd dié leefwêreld ook vir ' $n$ manlike pastor mag voorkom.

Vir vrouepredikante kan hierdie verwysingsraamwerk, juis omdat dit so bekend is, ' $n$ bedreiging inhou. Vroue wat predikant geword het, het die beperkings van die vroue-wêreld in ' $n$ sekere opsig oorstyg. Vir ' $n$ vrouepredikant om werklik in te voel in die verwysingsraamwerk van sommige vrouepastorante, sal beteken dat die predikant weer die "tradisionele" vrouewêreld empaties sal moet betree. Dit kan " $n$ angswekkende ervaring wees om weer die suigkrag van die wêreld wat die vrouepredikant met moeite ontsnap het, weer te ervaar. As vrouepredikante nie bewus word van moontlike ambivalensie ten opsigte van hulle vrouwees en ' $n$ weg daarmee vind nie, kan dit in die pad kom van egte pastorale kommunikasie met vroue in "tradisionele" rolle.

Waar vrouepastorante se gebrekkige persoonskap en nie-identiteit simmetriese kommunikasie in die wiele ry, sal pastors voorlopig sterk leiding neem om die bewusmakingsproses te fasiliteer. Pastors kan die vroue begelei om te kom tot aanvaarding van hulle God-gegewe waarde as volwaardige mense, tot ' $n$ volwasse, eie identiteit en ' $n$ egte ervaring van hulle persoonskap. Dikwels is dit 'n lang proses. Vanweë hulle lei- dende rol in hierdie verband sal pastors moet waak teen ' $n$ paternalistiese kommunikasiestyl en die rol van die "kundige" soos dit in die mediese model voorkom (Greenspan 1983:185; vgl ook die kritiese bydraes van Smith \& Douglas 1990:43-50; Lerman \& Rigby 1990:51-59; Lerman \& Porter 1990:5-13).

Hoewel die pastorant tydelik afhanklik is van die pastor se leiding, bly die einddoel haar volwaardige funksionering as mede-subjek binne die interaksie. Die begeleidingsproses sal sake soos haar gevoel van eiewaarde en selfvertroue, vertroue in haar eie gevoel, oordeel, mening en ervaring, asook die artikulasie van haar eie ervaring insluit. Daar bestaan soms heelwat blokkasies op al hierdie terreine in die geïnstitusionaliseerde leefwêreld van vroue. Ná die pastorale gesprek keer die vroue dikwels terug na ' $n$ leefwêreld waar van hulle verwag word om die tradisionele rol te vervul. Die gevolg is dat die positiewe resultaat van die pastorale interaksie dikwels daar en dan weer afgebreek word.

\section{ENKELE FOKUSPUNTE VIR PASTORAAT MET VROUE}

Vernuwing in die pastoraat met vroue behels ' $n$ simmetriese relasie tussen pastor en pastorant waarbinne daar saam gesoek word na weë om 'n outentieke lewe voor God te verwesenlik. Dit beteken dat wat in die pad staan van outentieke lewe voor God, blootgelê moet word. Vervolgens word hierdie proses kortliks beskryf.

\section{1 "Dis nie jou skuld nie"}

Vroue se persoonlike probleme behoort in die pastorale interaksie nie summier aan hulle "ontoereikendheid" toegeskryf word nie (vgl Greenspan 1983). Vroue moet van hulle gedetermineerde gedrag bewus gemaak word, sodat dit kan verander. Die strukture waarbinne vroue leef, sal geanaliseer moet word om hulle negatiewe kragte bloot te lê. Die tradisionele psigologie (kyk Bons-Storm 1996:92-93) het dikwels vroue se reaksies en gedrag getipeer as:

- "onvolwasse" (byvoorbeeld "selfsugtig" as sy iets vir haarself wil doen);

- "mal" (byvoorbeeld as sy intens negatief reageer op iets wat in die samelewing as goed en reg beskou word);

- en "ontoereikend" (byvoorbeeld, as sy in " $n$ depressie verval of spanningsverwante gesondheidsprobleme opdoen, word sy as "swak" beskou).

Hierdie gedrag kan egter verduidelik word as ' $n$ verstaanbare reaksies op en pogings om te probeer oorleef binne hiërargiese strukture wat nie vir vroue genoegsaam ruimte bied om te wees wie en wat hulle geskape is

ISSN 1609-9982 = VERBUM ET ECCLESIA Jrg 22 (1) 2001 
nie. Begrip van die pastor kan groot verligting by vroue meebring. Vroue se negatiewe ervaring verskaf data vir ' $n$ analise van wat as verkeerd, ongesond, beperkend, benouend en verwoestend beleef word. Die strukture onderliggend aan hierdie ervaring word blootgelê en ondersoek. Waar die strukture afbrekende en ongesonde gevolge vir mense het, word die opbou van nuwe moontlikhede bedink (kyk Berquist 1992:2-8).

\subsection{Die storie word gebore}

Genesing begin wanneer vroue hulle eie verhale vertel en hierdie verhale gehoor, aanvaar en gerespekteer word (vgl Bons-Storm 2000). Die pastorale grondhouding van luister, respek en empatiese kommunikasie is van kardinale belang. Luister is hier belangriker as ooit omdat vroue dikwels ervaar dat daar nie met erns na hulle geluister word nie (vgl Bons-Storm 1996). Vroue sal miskien selfs met die verwagting kom dat die pastor tog nie sal luister of verstaan nie. Hierdie vooroordeel sal in die pastorale interaksie afgebreek moet word. Luister is verder besonder belangrik omdat die pastor dikwels sal moet luister om te probeer hoor wat nie gesê kan word nie. Die luisterproses help die storie, wat soms as unstory (kyk Laird 1987:437) begin, om gebore te word.

Waar die tradisionele reaksie op wat vroue sê, dikwels van disrespek getuig, sal pastors spesifiek daarop moet let om te alle tye respekvol te reageer op wat vrouepastorante vertel. Om te glo wat vroue sê, en te bevestig dat hulle belewing en ervaring geldig is, is die kern van effektiewe pastoraat met vroue. ' $n$ Disrespekvolle afmaak van vroue se verhale sal die kommunikasie tot ' $n$ einde bring. Dit geld uiteraard vir alle pastorale interaksie, nie net dié met vroue nie. Maar met vroue kan die kulturele kondisionering (kyk Dreyer 1999a:51-65) naamlik om onbewustelik min aandag te bestee aan wat vroue sê en nie erns te maak met hulle storie nie, in die besonder lei tot 'n afbrekende pastorale praktyk. Pastors is dikwels nie eens bewus van hierdie onderliggende dinamiek nie.

Net soos die geboorte van vroue se verhale, kan dié wedersyds respekvolle interaksie tussen pastor en vrou ook 'n moeisame proses wees. Dit kan gestrem word deur vroue wat uitgelewer voel aan nieidentiteit of die onvermoë om te weet wat hulle werklik ervaar (vgl Rigsby 1994:40). Dikwels het vroue wat geen vertroue het in hulle eie ervaring, of die waarde daarvan betwyfel, moeite om dit te artikuleer. Wanneer vroue sukkel om hulle storie te vertel, moet pastors daarteen waak om te vinnig namens hulle met ' $n$ interpretasie vorendag te kom Dit sal net weer marginalisering beteken. Elke keer wanneer pastors só die leiding neem, bestaan die gevaar van teruggly in ' $n$ paternalistiese kommunikasiepatroon. 'n Grondhouding van radikale respek en deernis vir ' $n$ mens wie se ontwikkeling tot volle volwassenheid gestrem is, sal pastors van paternalisme weerhou. Die ontwikkeling van die vermoë om te weet wie sy is, wat sy dink en voel (tot identiteit en persoonskap) is fundamenteel deel van die genesingsproses.

\subsection{Moontlike oplossing}

Benewens die interpretasie van vroue se verhale, is moontlike oplossings vir die probleme ook nie op ' $n$ eensydige wyse die taak van die kundige pastor nie. Vrouepastorante en die pastors soek saam. Die pastor evalueer alle moontlikhede in die lig van wat psigologies, sosiologies en teologies gesond is. Die moontlikhede word ook deur die pastorant getoets aan haar kennis, insig, aanvoeling en intuïsie ten opsigte van haar menswees en situasie. Haar kennis en kundigheid ten opsigte van haar eie lewe is van kardinale belang in die pastorale interaksie. Dit is kennis waaroor die pastor met al sy of haar geleerdheid nie beskik nie. Die pastor se taak is weer eens om die vrouepastorant by te staan by die geboorte van oplossinggewende kennis. Hoe minder daar van vroue menswees oor was toe hulle kom anklop het om hulp, hoe moeiliker sal hierdie geboorteproses verloop.

Die moderne paradigma het in ' $\mathrm{n}$ groot mate gelei tot die beklemtoning van vroue se nie-identiteit en waardeloosheid. In ' $n$ simmetriese interaksie is albei partye gelykwaardige persone, kundiges op hulle eie terrein. Die kommunikatiewe interaksie geskied dus te alle tye op ' $n$ subjek-subjek as. Respek, oftewel naasteliefde (vgl Von Bendemann 1997), vervul ' $n$ belangrike rol wanneer vroue as volle mee-werkende subjekte saam soek na oplossings, saam soek na God se wil vir hulle lewe, en saam soek na Jesus as die menslike gesig van God (kyk Dreyer 1999b:70-96)

Jesus se boodskap van direkte toegang tot God teenoor die "bemiddelaarsrol" wat aan tradisies en godsdienstige gebruike toegeken is, het direkte implikasies vir die hiërargiese ordening van die kerklike praktyk. Dit sluit in om die eeue-oue bemiddeling van mans namens vroue te bevraagteken. Vroue wat dit in die pastorale interaksie moeilik vind om van die "God-gegewe" ordening van mans in magsposisies afstand te doen ter wille van hulle eie outentieke menswees voor God, kan met hierdie perspektief op die lewe en werk van Jesus gehelp word.

Jesus se radikale insluiting van almal wat volgens die heersende patriargale sisteem "onrein" of "identiteitloos" was, bevraagteken die geskiedenis van die kerk om sekere kategorieë mense, ook vroue, te marginaliseer. Die vraag aan die huidige kerklike praktyk is watter groepe vandag steeds deur die kerkgemeenskap na die rand gestoot word. Vroue wat ervaring het van die pyn van marginalisering, het dikwels ' $n$ groter deernis en respek vir sulke mense as die tradisioneeldenkende mense in kerklike magsposisies.

ISSN 1609-9982 = VERBUM ET ECCLESIA Jrg 22 (1) 2001 
Die Nuwe Testament se boodskap oor Jesus se onvoorwaardelike vergifnis van sondaars bevraagteken die kerklike praktyk se klem op orde ten koste van barmhartigheid. Vroue, wie se morele oordeel dikwels veel meer rekening hou met wie seer kry as met wie die reëls oortree en wie se regte aangetas word (vgl Gilligan 1982), se bydrae is van belang vir die kerklike praktyk.

\section{OUTENTIEKE LEWE VOOR GOD}

Om God te ontmoet, is outententieke lewe. Waar die heelheid, welsyn en outentieke lewe van vroue vir die kerk belangrik is, kan die Bybel en die teologiese tradisie nie meer téén vroue gebruik word nie. Selfs op die patriargaat in die leefwêreld van die Bybel val nou ' $n$ kritiese lig (kyk Jacobs-Malina 1993). Vroue hoef nie langer in die kerk pynlike marginalisering te beleef nie. Vroue se gawes en vermoëns sal nie langer afgemaak en gestereotipeer word, wat daartoe lei dat hulle slegs in ' $n$ beperkte ruimte as gelowiges kan funksioneer nie. Vroue se gawes sal hulle bydrae bepaal en nie hulle geslag nie. Hulle sal nie langer beperk word tot stereotipiese rolle en deur die Bybel self vermaan word om hulle daarby te hou nie.

Indien vroue se welsyn op die hart gedra word, sal die kerk nie daartoe bydra om vroue in hulle liggaamlikheid te verneder nie (kyk Schulenburg 1993:25, 26). Buite die kerk is die boodskap openlik en duidelik: vroue word verkrag, misbruik, geterroriseer, geteister (vgl Griffin 1986). Vroueliggame word vertoon langs ' $n$ gebruiksartikel om die artikel verkoop te kry. Die boodskap is: die een ding is so begeerlik soos die ander ding - koop dit! Prostitusie skreeu duidelik uit wat daar van vroueliggame gedink word, en so ook pornografie (vgl Griffin 1981).

In die kerk behoort vroue nie gereduseer te word tot hulle liggaamlikheid, tot woman as body (vgl Daly 1979; Greenspan 1983; Haddon 1988) nie. So, byvoorbeeld, word vroue gereduseer tot hulle reproduktiewe funksie, naamlik om die moederrol te verheerlik as die enigste aanvaarbare staat vir vroue. ' $n$ Ander voorbeeld is wanneer seksualiteit op ' $n$ onredelike wyse bygetrek word waar vroue ter sprake is. Op dié manier word vroue se menswees afgemaak tot niks anders nie as hulle seksuele liggaamlikheid. In die kerklike praktyk is daar talle voorbeelde waar vroue dit ervaar, seerkry en terugtrek, want hierdie vorm van vernedering is by uitstek ' $n$ skande-ervaring (vgl Rigsby 1994:58). Ander soorte pyn word met mense (vriende en/of familie) gedeel, maar skandeervarings isoleer. Die psigiese las word alleen gedra. Om vroue te behandel soos seksobjekte en hulle in hulle liggaamlikheid te verneder, is om ten diepste minagting en vrouehaat (misogyny) te kommunikeer.
"Outentiek" beteken onder meer eg. Outentieke lewe is " $n$ lewe sonder distorsies in verhouding met God, self en mede-mens. Egte menswees en menswaardigheid maak deel uit van outentieke lewe. Outentieke lewe vir vroue is om te wees wie en wat God hulle geskape het, sonder stereotipiese distorsies. Pastors en die pastorante behoort voortdurend bewus te bly daarvan dat God aan elke individu gawes gee, ook aan vroue. Vroue is gestereotipeer as swak, sag en passief. Wat nie by die stereotipes inpas nie, is geëttiketteer as "onvroulik" en dus onaanvaarbaar. Vroue moes hulle "onaanvaarbare", "onvroulike" gawes of vermoëns (soos bv krag en intelligensie) wegsteek, en hulle menswees verwring, om in te pas by sosiale konstrukte (vgl Schulenburg 1993:28-29; vgl Schüssler Fiorenza 1996b:xvii). Dit beteken onegte lewe.

Vir vroue is rolle en take voorgeskryf. Hulle is verantwoordelik gehou vir kinders en huiswerk, hoewel mans ook kinders het en in huise woon. Mans is verantwoordelik gemaak vir die ekonomiese sy van die gesin se bestaan. Met vroue se toelating tot die openbare werksfeer, is vroue mede-verantwoordelik vir die ekonomiese, maar hulle werklas tuis het nie noemenswaardig verminder nie (kyk Rabin \& Shapira-Berman 1997:319-320).

Outentieke lewe sou beteken dat vroue ten volle, met alles wat God hulle gegee het, kan bydra tot die samelewing. Outentieke lewe raak alle terreine waarop vroue hulle bevind. Wat op hierdie lewensterreine gebeur, watter boodskappe vroue ontvang van die samelewing, van "God" (hoe die Bybel aangewend word deur die kerk en pastors) is ter sake in pastorale interaksie.

Veral twee terreine wat in vroue se lewens van bepalende belang is en wat in pastorale interaksie aan die orde sal kom, is die huwelik en die werksituasie. Op albei hierdie lewensterreine is die moontlikheid sterk dat pastors nie vernuwend binne die veranderde paradigma in interaksie met vrouepastorante sal tree nie. Op hierdie twee terreine word vroue se lewens dikwels nog bepaal deur ' $n$ modernistiese hantering van Bybelseteologiese "norme" en samelewingskonvensies. Dit dra weer eens by tot die nie-identiteit van vroue. Indien pastors hier nie vernuwend en kreatief werk in hulle pastoraat nie, kan hulle die skade wat reeds aan vroue berokken is, vererger.

\subsection{Outentieke lewe en die huweliksverhouding}

Daar is nog min voorbeelde van huweliksverhoudings waar albei volwassenes volle verantwoordelikheid aanvaar vir alle volwasse verpligtinge en albei ' $n$ volle bydrae lewer tot familie en samelewing vanuit hulle God-gegewe gawes en talente. Daar is wel pogings tot die vorming van ' $n$ egalitêre huweliksverhouding (kyk Walsh 1989:272). Die tradisionele huwelik word nie noodwendig meer as die enigste of "eintlike"

ISSN 1609-9982 = VERBUM ET ECCLESIA Jrg 22 (1) 2001 
moontlikheid beskou nie. As albei persone in die relasie nie soortgelyk daaroor dink nie, kan dit probleme veroorsaak. Daar is byvoorbeeld vroue wat ' $n$ egalitêre huwelik verwag en dan vind dat hulle mans, hoewel in beginsel daarvóór, nie vir die volle implikasies daarvan kans sien nie. Daar is mans wat ' $n$ gelyke maat verwag en dan vind dat hulle vroue, hoewel in beginsel daarvóór, dit nie regkry om los te breek uit die stereotipiese vrouerolle nie.

\subsection{Outentieke lewe en die werksituasie}

Outentieke lewe vir alle volwassenes sou beteken dat alle take en verantwoordelikhede op ' $\mathrm{n}$ regverdige wyse gelyk verdeel word (kyk die publikasie van die Verenigde Volke getitel Women: Challenge to the year 2000 [1991:10]; vgl ook Praetorius 1998; Holder \& Anderson 1989). Dit beteken dat die een groep nie op grond van geslag bevoorreg word, en meer kan hê van wat aangenaam en vervullend is en die ander meer van wat onaangenaam en vervelend is nie. In die werksituasie beteken dit dat werkgewers behoort ruimte te maak vir die feit dat al hulle werknemers mense met huislike verpligtings en verantwoordelikhede is. Die feit dat kinders tot dusver hoofsaaklik een ouer se verantwoordelikheid was, het dit vir werkgewers onvoordelig gemaak om die meesbelaste persoon in diens te neem. Om die ouer sonder hierdie belasting in diens te neem, het beteken dat die werkgewer kon staatmaak op ' $n$ onbetaalde ondersteunende sisteem by die huis, wat die werknemer in staat stel om meer te gee en te doen by die werk. Werkgewers behoort nie reg hierop te hê nie. Pastors behoort die onregverdigheid hiervan uit te lig en dit nie as ' $n$ vanselfsprekende werklikheid van vroue se bestaan te aanvaar en voort te sit nie.

\section{HEIL EN WELSYN IN POSTMODERNE PASTORAAT}

Postmoderne pastoraat onderskei nie tussen die heil van mense en hulle welsyn nie. Vanuit ' $n$ holistiese perspektief word outentieke lewe voor God gesien as ineengeweef met alle aspekte van menswees. Hierdie saak word bevestig deur die houding van Jesus van Nasaret teenoor gemarginaliseerdes. Die doel van die praktiese teologie is nie om ' $n$ "finale" praktykteorie vir die pastoraat op te stel nie. ' $n$ Dinamiese woordgebeure vra om gedurig met die evangelie van Jesus van Nasaret gekonfronteer te word. Die klem wat op bewusmaking gelê word, geskied dus nie net vanuit ' $n$ epistemologie van deelname aan die evangelie nie, maar om sonder ophou te bly vra wat die inhoud en implikasies van die evangelie in veranderende tye is. Die hart van die evangelie kom neer op God se onbeperkte en onbegrensde genade vir alle mense.

\section{Literatuurverwysings}

Berquist, J 1992. Reclaiming her story: The witness of women in the Old Testament. St Louis, Missouri: Chalice Press.

Beukes, C J 1996. Michel Foucault en die historisering van Anderswees. Hervormde Teologiese Studies 52(2\&3), 233-251.

Bons-Storm, R 1996. The incredible woman: Listening to women's silences in pastoral care and counseling. Foreword by P D Couture. Nashville: Abingdon Press.

Bons-Storm, R 2000. Kracht en kruis: Kampen: Kok.

Conn, J W 1986. Women's spirituality: Restriction and reconstruction, in Conn, J W (ed), Women's Spirituality: Resources for Christian development, New York: Paulist Press, 9-30.

Cronjé, J M \& Van Wyk, J A 1982. Van mens tot mens: Kerklike kommunikasie in teorie en praktyk. Pretoria: NG Kerkboekhandel.

Daly, M 1979. Gyn/Ecology: The metaethics of radical feminism. Boston: Beacon.

Dreyer, Y 1998. Feministiese hermeneutiek as kritiese teorie. Hervormde Teologiese Studies 54(3\&4), 623-651.

Dreyer, Y 1999a. Vroue en die sosio-kulturele narratief. Skrif en Kerk 20(1), 51-65. Dreyer Y 1999b. Jesus en vroue. Hervormde Teologiese Studies 55(1), 70-96.

$\mathrm{Du}$ Toit, B 2000. God? Geloof in 'n postmoderne tyd. Bloemfontein: CLF Uitgewers.

Gilligan, C 1982. In a different voice. Cambridge, MA: Harvard University Press.

Greenspan, M 1983. A new approach to women in therapy. New York: McGrawhill.

Griffin, S 1981. Pornography and silence: Culture's revenge against nature. New York: Harper \& Row

Griffin, S 1986. Rape, the politics of consciousness. San Francisco: Harper \& Row.

Haddon, G P 1988. Body metaphors: Releasing God-feminine in us all. New York: Crossroad.

Hamerton-Kelly, R 1979. God the father: Theology and patriarchy in the teaching of Jesus (Overtures to Biblical theology) Philadelphia: Fortress.

Heitink, G 1990. Geloof en geestelijke gezondheid, in Heitink, G \& Veenhof, J (reds), Heil, heling, gezondheid, 's Gravenhage: Meinema 56-69.

Holder, D P \& Anderson, C M 1989. Women, work and the family, in McGoldrick et al, Women in families: A framework for family therapy, 357-380.

Jacobs-Malina, D 1993. Beyond patriarchy: The images of family in Jesus. New York: Paulist.

Kuhn, T S 1970. The structure of scientific revolutions. Chicago, Illinois: University of Chicago Press.

Kuhn, T S 1977. Second thoughts on paradigms, in Kuhn, T S, The essential tension Selected studies in scientific tradition and change, Reprinted from The structure of scientific theories. Chicago: Chicago University Press, 293-339.

Küng, $\mathrm{H}$ 1988. Theology for the third millennium: An ecumenical view, tr by $\mathrm{P}$ Heinegg. New York: Doubleday.

Küng, H 1991. Global responsibility: In search of a new world ethic, tr by R Piper. : New York: Crossroad.

Laird, J 1989. Women and stories: Restorying women's self-constructions, in McGoldrick et al (ed), Women and families: A framework for family therapy. New York: Norton. 
Lemmen, M M W 1990. Max Weber's sociology of religion: Its method and content in the light of the concept of rationality. Hilversum: Uitgeverij Gooi en Sticht.

Lerman, H \& Porter, N 1990. The contribution of feminism to ethics in psychotherapy, in Lerman, $\mathrm{H} \&$ Porter, $\mathrm{N}$ (eds), Feminist ethics in psychotherapy, New York: Springer, 5-13.

Lerman, H \& Rigby, D N 1990. Boundary violations: Misuse of the power of the therapist, in Lerman, H \& Porter, N (eds), Feminist ethics in psychotherapy, 51-59. New York: Springer.

Matthews, V H \& Bejamin, D C 1993. Social world of ancient Israel: 1250-587 BCE. Peabody, MA: Hendrickson.

McGoldrick, M, Anderson, C M \& Walsh, f 1989. Women in families:j A framework for family therapy. New York: Norton.

Mollenkott, V R 1992. Sensuous spirituality: Out from fundamentalism. New York: Crossroad.

Mouton, J 1987. Die positivisme, in Snyman, J J \& Du Plessis P G W (reds), Wetenskapsbeelde in die geesteswetenskappe, Pretoria: RGN (RGN-Studies in Navorsingsmetodologie 3) 1-29.

Nauta, R 1996. Psychological dynamics of pastoral identity. Journal of Empirical Theology 9/1, 51-68.

Pilch, J J 1996. Altered states of consciousness: A "kitbashed" model. Biblical Theology Bulletin 26/3, 133-138.

Praetorius, I 1998. Re-thinking economy: Beyond the androcentric order. Feminist Theology 17, 89-102.

Rabin, C \& Shapira-Berman, O 1997. Egalitarianism and marital happiness: Israeli wives and husbands on a collision course? The American Journal of Family Therapy 25/4, 319-330.

Rigsby, R K 1994. Jungians, archetypalists, and fear of feminism, in Lawler, J G (ed), The 1994 Annual of Hermeneutics \& Social Concern, 35-58. New York Continuum.

Romm, N 1987. Habermas se wetenskapsteorie, in Snyman \& Du Plessis 1987:179. 197.

Schulenburg, A 1993. Feministische spiritualität: Exodus in eine befreiende Kirche? Stuttgart: Kohlhammer.

Schüssler Fiorenza, E 1983. In memory of her: A feminist theological reconstruction of Christian origins. New York: Crossroad.

-, 1996a. For women in men's world: A critical feminist theology of liberation, in Schüssler Fiorenza, E (ed), The power of naming: A Concilium reader in feminist liberation theology, 3-13. Maryknoll, NY: SCM.

-, 1996b. Introduction: Feminist liberation theology as critical Sophialogy, in Schüssler Fiorenza, E (ed), The power of naming: A Concilium reader in feminist liberation theology, xiii-xxxix. Maryknoll, NY: SCM.

-, 1999. Rhetoric and ethic: The politics of Biblical study. Minneapolis, MN: Fortress.

Smith, A J \& Douglas, M A 1990. Empowerment as an ethical imperative, in Lerman, $\mathrm{H} \&$ Porter, $\mathrm{N}$ (eds), Feminist ethics in psychotherapy, 43-50. New York: Springer.

Snyman, J J 1987. Die wetenskapsopvatting van die Frankfurtse Skool, in Snyman \& Du Plessis 1987:155-177.

Snyman, J J \& Du Plessis, P G W (reds) 1987. Wetenskapsbeelde in die geesteswetenskappe. Pretoria: RGN.
Snyman, J J 1995. Postmodernism, art and aesthetics, in Rossouw, G J (ed), Life in a postmodern culture, 63-73. Pretoria: HSRC Publishers.

Sölle, D 1996. Paternalistic religion, in Schüssler Fiorenza, E (ed), The power of naming: A Concilium reader in feminist liberation theology, 150-158. Maryknoll, NY: SCM.

Stegemann, E W \& Stegemann, W 1995. Urchristliche Sozialgeschichte: Die Anfänge im Judentum und die Christusgemeinden. Stuttgart: Kohlhammer.

Van Huyssteen, W 1986. Teologie as kritiese geloofsverantwoording: Teorievorming in die sistematiese teologie. (RGN-Studies in Navorsings-metodologie 2.) Pretoria: RGN

Von Bendemann, R 1997. Das Liebesgebot als Kristallisationspunkt und Testfall neutestamentlicher Ethik: Eine Skizze. Glaube und Lernen: Zeitschrift für theologische Urteilsbildung 12/2, 124-135.

Von Wartenberg-Potter, B 1987. We will not hang our harps on the willows: Engagement and spirituality. Geneva: WWC Publications.

Vos, C J A \& Pieterse, H J C 1997. Hoe lieflik is u woning. Pretoria: Raad vir Geesteswetenskaplike Navorsing.

Walsh, F 1989. Reconsidering gender in the marital quid pro quo, in McGoldrick et al (eds), Women in families: A framework for family therapy, ??? 267-285.

Weber, M [1947]1968. Max Weber: On charisma and institution building. Selected papers edited and with an introduction by E N Eisenstadt. Chicago, University of Chicago Press.

Wilshire, D 1992. The uses of myth, image and the female body in revisioning knowledge, in: Jaggar, A M \& Bordo, S R (eds), Gender/body/knowledge: Feminist reconstruction of being and knowing. New Brunswick, Rutgers University Press.

Women: Challenges to the year 2000 1991. New York: United Nations Department of Public Information. 